\title{
ON ALBUMINURIC ULCERATION OF THE BOWELS.
}

\author{
BY \\ W. HOWSHIP DICKINSON, M.D., \\ HONORARY FELLOW OF OAIUS COLLEGE, CAMBRIDGE; FELLOW OF THE \\ ROYAL COLLEGR OF PHYSICIANS; SFNIOR PHYBICIAN TO ST. \\ GEORGE'S HOSPITAL; CONSULTING PHYSICIAN TO THE \\ HOSPITAI FOR SICK CHILDREN.
}

Received July 26th, 1893-Read January 9th, 1894.

I PRESUME to bring before the Society an accompaniment and result of renal disease to which I have formerly briefly referred, but which has not yet received the notice which is due to it, whether as regards its pathological interest or its vital importance. I am not aware that the concurrence of ulceration of the bowel with albuminuria found mention until 1876, when, in the Croonian Lectures of that year, I ventured to adduce two cases of this enteric lesion in connection with the granular kidney, unexplained by either typhoid or tubercle and not to be accounted for otherwise than as related in some manner to the renal disease. ${ }^{l}$ The late Dr. Greenhow presently enabled me to add a third, which, with the two before mentioned, was cited in my second edition of 'Albuminuria' in 1877, with the recognition that the intestinal change resulted from the renal,

1 ' British Medical Journal,' April 22nd, 1876, p. 560. 
though at that time it was not apparent how the association was brought about. In the following year I called the notice of the Pathological Society to a case of " Ulceration of the Bowel as a Consequence of Renal Disease," I with the particulars of a microscopic examination of the bowel, made by my former clinical clerk Mr. A. Shann, which revealed the hæmorrhagic nature of the process.

During the considerable time which has passed since these observations were published I have been on the watch for the enteric complication of albuminuria, which has long taken its place-at St. George's at least-among the things to be looked for in post-mortems relating to renal disease. I now propose to ask the attention of the Society to the experience which has accumulated, making use not only of my own cases, but also of those which have occurred in the practice of my colleagues, to whom I tender my thanks for their permission to do so. To avoid the length and tediousness of complicated narratives, I have condensed the records into a tabular form, which will present in brief the essential particulars. These have been for the most part gathered from the hospital post-mortem books, though I have occasionally been able to refer to my own notes in addition. The observations extend over forty years. The first case came under my notice when I was clerk to the late Dr. Bence Jones, though the connection of the ulceration with the renal disease was not recognised until later instances had thrown a backward light upon it, and enabled it to be recovered from a remote past to illustrate comparatively recent pathology.

I have brought together twenty-two cases of ulceration of the bowel, concurrent with albuminuria and not with any other condition by which the enteric lesion could be explained. In two of them there was also ulceration of the stomach, possibly of the same nature, and a single instance will be found concerning the same organ which must be ad1 'Path. Soc. Trans.,' vol. xxix, p. 117. 
mitted to be of doubtful value, though of some interest in relation to the conditions under which it occurred. I have appended, with design to throw light upon the morbid process, eight instances of extravasation of blood without ulceration, but similar in place and circumstances to it.

With regard to the bowel, the ulceration was confined to the small intestine in eleven cases; confined to the large intestine in five cases; in five both were affected. In one the position of the ulceration was not more exactly defined than as "near the cæcum." Within the small bowel the region most frequently affected was the ileum, though no part was exempt. In the large bowel the colon suffered with the greatest frequency, though the cæcum was affected alone or with other parts of the bowel in three instances.

The ulcers were not associated in particular with any of the glandular structures of the intestines, but affected the mucous membrane without any obvious preference excepting in general terms for the lower part of the ileum. Peyer's patches were usually exempt, though in one instance (that of Williams) they were involved. The solitary glands of the cæcum were recorded in one case as intensely congested but not ulcerated. In several the valvulæ conniventes were found to be either ulcerated or congested, so that if the morbid process have any special choice, however rarely exercised, it would seem to be for these structures. In size the ulcers varied from two inches by one to spots no larger than the marks of raindrops. The ulcers were usually regular in shape, more or less circular, without thickening, and with "punched" edges. In some instances the ulcerated surface had become covered, as if by a process of healing, with a delicate membranous film (Jackson, Hissgen).

The most conspicuous characters of the morbid change were derived from hæmorrhage, old and new, in the neighbourhood of the ulcers. Pigmented stains and recent ecchymoses were common-the latter in situations, such as the edges of the valvulæ conniventes, where the vOL. LXXVII. 
ulcerative process has been known to declare itself. The most important characteristic of the ulcers is their tendency to perforate and set up peritonitis, in other words their deep origin or penetrating character.

This introduces the minute anatomy of the ulcers and the morbid process to which they are due. The most constant factor, and that which presents itself as of the greatest significance, is extravasation of blood. The earlier observations which led to this conclusion have been corroborated by more recent ; I may refer especially to some microscopic examinations which $\mathrm{Mr}$. Fenton has recently undertaken at my request. These relate to two preparations in our museum which had not hitherto been examined in section. They belonged to the cases of Hissgen and Parker; and though they had been for fourteen years in spirit, there was no difficulty in recognising the hæmorrhage connected with the ulcers. It is probable that the effusion of blood in the submucous coat, which has been microscopically demonstrated in three instances, is the primary and essential lesion upon which the ulceration is consequent. The general fact of effusion of blood in connection with these ulcers rests on a much wider foundation than the few cases where it has been described with microscopic minuteness. Not only are ecchymoses and pigmentations continually associated with the ulcers, but intestinal hæmorrhages, particularly in the submucous coat, are not infrequently observed without ulceration in connection with advanced renal disease, hypertrophy of the heart, and retinal hæmorrhage. I have annexed a table which displays eight cases of this nature.

Besides the ulceration which has been described as belonging to the intestine, I have brought together three cases in which the stomach presented a similar change in similar circumstances. In two of these the stomach was ulcerated together with the bowel, and possibly by a similar process. One of the subjects was a child of eight, an age at which ulceration of the stomach is exceedingly rare. In this instance the gastric ulcer was surrounded by traces of 
old hæmorrhage, while similar signs were abundant about the ulcers in the intestine. Putting aside the evidence of hæmorrhage in the stomach in this instance, the gastric ulcers were not noticeably different from those of common experience.

Putting all the observations together, we recognise in connection with chronic albuminuria a peculiar form of ulceration of the bowel which is associated with, and probably produced by, submucous hæmorrhage ; while similar hæmorrhage also presents itself in the same circumstances unattended by ulceration. There is reason to believe that the stumach may, however rarely, participate in the same process.

I will take brief note of what may be called the foreign relations of the intestinal lesion and the association of hæmorrhage in the bowel with hæmorrhage elsewhere. In the total of twenty-two cases where the intestine was ulcerated, with or without the stomach, the retinø were the seat of albuminuric changes, hæmorrhagic or otherwise, in nine. In the same series hypertrophy of the heart was recorded in nineteen, as if the intestinal lesion were but one of the cardio-vascular series.

Looking at the conditions of kidney found together with this ulceration in the twenty-two cases referred to, advanced fibrosis was present in all but two; in fourteen cases the kidneys were described as granular; in four as fibrotic, or in a state of interstitial nephritis; in two as well-marked examples of the large white kidney of nephritis. Assuming, as we may, that the large white kidneys were affected with interstitial as well as tubal inflammation, it is to be concluded that twenty of the twenty-two were in some phase of advanced renal fibrosis. Reverting to the two exceptional cases where renal fibrosis was not recognised: in one (Powell) the kidneys were certainly the seat of old disease, and were probably fibrotic, though not assuredly so. They were irregular in shape, had adherent capsules, and one presented a cicatricial depression. The other (Louisa Booth) was a case of lar- 
daceous disease which has especial interest in relation to the ulceration of the bowel. The lardaceous disease was not the cause of the ulceration, but its result. There had been general dropsy, presumably renal, at the age of twelve. This appears to have been succeeded by the special ulceration, perforation, and a circumscribed abscess within the peritoneal cavity. The consequent profuse discharge by the bowel led to general lardaceous disease which superseded or masked the renal mischief, and proved fatal at the age of twenty-one.

The symptoms of this complication of renal disease present themselves usually towards the fatal close, though there is evidence in old cicatrices found after death that the ulceration is not always immediately fatal. The symptoms are those of bowel irritation, sometimes such as might belong to dysentery, with which are often associated those of peritonitis and perforation. In the course of these there may be certain reminiscences of uræmia ; it is difficult to say how far the occasional obstinate vomiting may have this origin, though other manifestations of the uræmic state appear to be much in abeyance when those of the intestinal lesion are prominent.

The post-mortem observations before us show that peritonitis was present in about a third of the cases, in seven of twenty-two; and that perforation had occurred about half as often, in four of the number. The symptoms of irritation of the bowel are diarrhcea and griping. The diarrhœa is by no means always present; there may indeed be constipation and a need for purgatives. The diarrhœa is sometimes profuse, and the chief cause of the prostration which in these cases is apt to be the mode of death. The motions are often liquid, and like those of typhoid; rarely they contain mucus. The griping pain is often prominent, and is most marked after food. A boy (Charles Dodd), who suffered much in this way and died with peritonitis and perforation, furnished his own diagnosis as "a twisting of the guts." He had served a butcher and acquired the rudiments of anatomy. 
One of the most noticeable symptoms is vomiting, which is often frequent and either spontaneous or readily provoked. A woman (Maria Jackson), under Dr. Bence Jones, had so much vomiting that for a time her disorder was attributed not to the kidneys but the stomach; sickness had been habitually induced by the sight of food and even by the sound of the dinner-bell. In some of the cases recorded it was a matter of doubt how far the vomiting was dependent on the state of the bowels and peritoneum, and how far uræmic. This symptom appeared most prominently when peritonitis was present. Hiccough was occasionally noticed.

Death is usually brought about by prostration and collapse, due either to the diarrhœe or to the peritonitis with or without perforation. Delirium was present towards the close in three of the twenty-two cases. The advent of the abdominal symptoms is usually succeeded by death in no long time; in five cases where this interval was recorded it varied from two days to over two months. In one which has been already referred to (Louisa Booth) there was evidence of albuminuric ulceration a year before death, which led to perforation, a circumscribed abscess, profuse purulent discharge, and lardaceous disease. In a minority of the cases (nine of twenty-two) no bowel symptoms were noted.

Without occupying the time of the Society with considerations which must be obvious, I will rest content with having invited attention, and that in somewhat more detail than before was possible, to a result of chronic renal disease which has hitherto received little notice, but which apparently belongs to a well-known class, for it is presumably of hæmorrhagic origin, is akin to the retinal alterations, and has relation to the cardio-vascular changes of which hypertrophy of the heart is the most constant indication.

The enteric manifestation has interest clinically as well as pathologically, for it commonly foretells the 
118 ALBUMINURIC ULCERATION OF THE BOWELS.

approach of the fatal ending, and often brings it about in modes which have been sufficiently denoted.

In conclusion, I have to record my obligation to Mr. William J. Fenton for making the microscopic observations to which I have already referred in connection with his name, and to Dr. Rolleston for assisting him. 


\section{TABLES OF CASES.}


Cases of Albuminuric

\begin{tabular}{|c|c|c|c|c|c|c|c|}
\hline $\begin{array}{c}\text { Name, physician, } \\
\text { date. }\end{array}$ & Age. & $\begin{array}{c}\text { Cause of renal } \\
\text { disease. }\end{array}$ & $\begin{array}{c}\text { Duration } \\
\text { of renal } \\
\text { symptoms. }\end{array}$ & Urine. & Kidneys, P.M. & Heart, P.M. & Retinæ. \\
\hline $\begin{array}{c}\text { Maria } \\
\text { Jackson. } \\
\text { Dr. Bence } \\
\text { Jones, 1853. } \\
\text { Croonian } \\
\text { Lectures, } \\
1876\end{array}$ & 30 & - & 6 months & $\begin{array}{c}\text { Highly } \\
\text { albuminous, } \\
\text { sometimes } \\
\text { bloody; } \\
\text { low sp. gr.; } \\
\text { casts }\end{array}$ & $\begin{array}{c}\text { Granular, } \\
\text { contracted; } \\
\text { arteries } \\
\text { thickened } \\
\end{array}$ & L.V. hyper- & $\begin{array}{c}\text { Much } \\
\text { dimness of } \\
\text { sight }\end{array}$ \\
\hline $\begin{array}{c}\text { Charles Dodd. } \\
\text { Dr.Dickinson, } \\
1872 . \\
\text { Croonian } \\
\text { Lectures, } \\
1876\end{array}$ & 14 & $\begin{array}{c}\text { Stone? } \\
\text { lithotrity } \\
\text { at age of } 3\end{array}$ & 3 years & $\begin{array}{c}\text { Trace of } \\
\text { albumen; } \\
\text { casts; } \\
\text { pale; low } \\
\text { sp. gr. }\end{array}$ & $\begin{array}{c}\text { Granular, } \\
\text { contracted, } \\
\text { fibrotic ; } \\
\text { right atro- } \\
\text { phied from } \\
\text { stone }\end{array}$ & $\mid \begin{array}{c}\text { L. V. much } \\
\text { hyper- } \\
\text { trophied; } \\
\text { weight } 8 \text { oz. }\end{array}$ & $\begin{array}{c}\text { Advanced } \\
\text { albumin- } \\
\text { uric } \\
\text { retinitis }\end{array}$ \\
\hline $\begin{array}{c}\text { Thomas } \\
\text { Wilding. } \\
\text { Dr. Whipham, } \\
1878\end{array}$ & 39 & $\begin{array}{c}\text { A great } \\
\text { drunkard; } \\
\text { scarlatina } \\
\text { in infancy }\end{array}$ & $\begin{array}{c}\text { Edema } \\
2 \frac{1}{2} \\
\text { months }\end{array}$ & $\begin{array}{c}\text { Highly } \\
\text { albumin- } \\
\text { ous, some- } \\
\text { times } \\
\text { bloody }\end{array}$ & $\begin{array}{c}\text { Granular, } \\
\text { contracted; } \\
\text { weight } \\
8 \frac{1}{2} \text { oz. }\end{array}$ & $\mid \begin{array}{c}\text { Hyper- } \\
\text { trophied; } \\
\text { weight 18 } \\
\text { oz.; recent } \\
\text { pericarditis }\end{array}$ & - \\
\hline $\begin{array}{c}\text { Francis J. } \\
\text { Williams. } \\
\text { Dr.Dickinson, } \\
\text { 'Path.Trans., } \\
\text { vol. xxix, } \\
\text { p. 117, 1878 }\end{array}$ & 20 & $\begin{array}{c}\text { Scarlatinal } \\
\text { dropsy at } \\
\text { age of } 6\end{array}$ & $\begin{array}{c}14 \text { years } \\
(?) ; \\
\text { polyuria } \\
2 \text { years }\end{array}$ & $\begin{array}{c}\text { Highly } \\
\text { albumin- } \\
\text { ous; casts; } \\
\text { pale, } \\
\text { copious }\end{array}$ & $\begin{array}{c}\text { Granular, } \\
\text { contracted, } \\
\text { fibrotic ; } \\
\text { weight } 8 \text { oz. }\end{array}$ & $\begin{array}{c}\text { L.V. hyper- } \\
\text { trophied ; } \\
\text { weight } \\
15 \mathrm{oz} .\end{array}$ & $\begin{array}{c}\text { Advanced } \\
\text { albumin- } \\
\text { uric } \\
\text { retinitis }\end{array}$ \\
\hline $\begin{array}{c}\text { William } \\
\text { Shrapnell. } \\
\text { Dr. Whipham, } \\
1878\end{array}$ & 24 & - & $\begin{array}{c}2 \frac{1}{s} \\
\text { months }\end{array}$ & $\begin{array}{l}\text { Highly } \\
\text { albumin- } \\
\text { ous; pale }\end{array}$ & $\begin{array}{c}\text { Very } \\
\text { granular; } \\
\text { weight } \\
11 \mathrm{oz.}\end{array}$ & $\begin{array}{c}\text { Enormous } \\
\text { hypertro- } \\
\text { phy of L.V.; } \\
\text { weight 39 } \\
\text { oz.; recent } \\
\text { pericar- } \\
\text { ditis ; } \\
\text { pulmonary } \\
\text { apoplexy }\end{array}$ & - \\
\hline
\end{tabular}


Ulceration of the Bowels.

\begin{tabular}{|c|c|c|c|}
\hline Renal symptoms. & Bowel symptoms. & Ulceration, P.M. & $\begin{array}{l}\text { Disease } \\
\text { bearing } \\
\text { on ulce- } \\
\text { ration. }\end{array}$ \\
\hline $\begin{array}{l}\text { No dropsy; obsti- } \\
\text { nate vomiting } \\
\text { throughout, } \\
\text { thought to be } \\
\text { uræmic; epistaxis }\end{array}$ & $\begin{array}{l}\text { Obstinate vomit- } \\
\text { ing; latterly grip- } \\
\text { ing abdominal pain } \\
\text { and diarrhœa. } \\
\text { Died of peritonitis }\end{array}$ & $\begin{array}{l}\text { Turbid fluid in peritoneum; intestines glued } \\
\text { together by recent lymph. Lower half of } \\
\text { ileum thickened; showed red and dark } \\
\text { patches of discoloration, and patches of } \\
\text { ulceration of no great depth covered with } \\
\text { thin membrane. Colon natural }\end{array}$ & None. \\
\hline $\begin{array}{l}\text { No dropsy ; fre- } \\
\text { quent headaches; } \\
\text { obstinate vomiting } \\
\text { regarded as } \\
\text { uræmic; convul- } \\
\text { sions }\end{array}$ & $\begin{array}{c}\text { Obstinate vomit- } \\
\text { ing ; griping pains } \\
\text { in belly; abdo- } \\
\text { minal tenderness ; } \\
\text { diarrhœa }\end{array}$ & $\begin{array}{l}\text { Recent peritonitis. Lower two feet of ileum } \\
\text { contained many ulcers, some of which } \\
\text { were linear and corresponded with val- } \\
\text { vulø conniventes; these often exposed } \\
\text { peritoneum. Mucous membrane between } \\
\text { swollen }\end{array}$ & None. \\
\hline $\begin{array}{l}\text { Edema, ascites, } \\
\text { vomiting }\end{array}$ & $\begin{array}{c}\text { Latterly diarrhœa } \\
\text { and vomiting, } \\
\text { with epigastric } \\
\text { pains, especially } \\
\text { after meals }\end{array}$ & $\begin{array}{l}\text { Small echymoses, especially on valvulæ } \\
\text { conniventes. In colon, for two feet below } \\
\text { valve, small star-shaped and elongated } \\
\text { ulcers, the latter transverse; edges con- } \\
\text { gested }\end{array}$ & None. \\
\hline $\begin{array}{c}\text { No dropsy after } \\
\text { original attack; } \\
\text { great arterial } \\
\text { tension, epistaxis; } \\
\text { dyspepsia, } \\
\text { vomiting }\end{array}$ & $\begin{array}{l}\text { Nausea, vomiting, } \\
\text { griping abdominal } \\
\text { pain, tenderness ; } \\
\text { pain, especially } \\
\text { after food ; con- } \\
\text { stipation, needed } \\
\text { purgatives ; mucus } \\
\text { in motions }\end{array}$ & $\begin{array}{l}\text { Purulent fluid in peritoneum. Many small } \\
\text { ulcers in ileum, mostly in Peyer's patches, } \\
\text { clean cut as if punched out, three of which } \\
\text { had perforated. Lower half of ileum con- } \\
\text { gested and pigmented. Colon pigmented } \\
\text { and ecchymosed. Microscopic sections of } \\
\text { ileum showed dark pigment mixed with } \\
\text { blood crystals in submucous coat }\end{array}$ & None. \\
\hline $\begin{array}{l}\text { No dropsy ; } \\
\text { hæmoptysis, } \\
\text { dyspnces }\end{array}$ & $\begin{array}{c}\text { No local } \\
\text { symptoms ; } \\
\text { constipation, } \\
\text { needed purgatives }\end{array}$ & $\begin{array}{l}\text { Numerous ulcers in lower part of ileum and } \\
\text { upper part of colon. In colon ulcers } \\
\text { numerous near valve. In the middle of } \\
\text { the ileum two old, practically healed } \\
\text { ulcers, large as Peyer's patches. Recent } \\
\text { ulcers small, roughly circular, and with } \\
\text { raised edges. Hæmorrhages and pigmen- } \\
\text { tation about ulcers. No peritonitis }\end{array}$ & None. \\
\hline
\end{tabular}




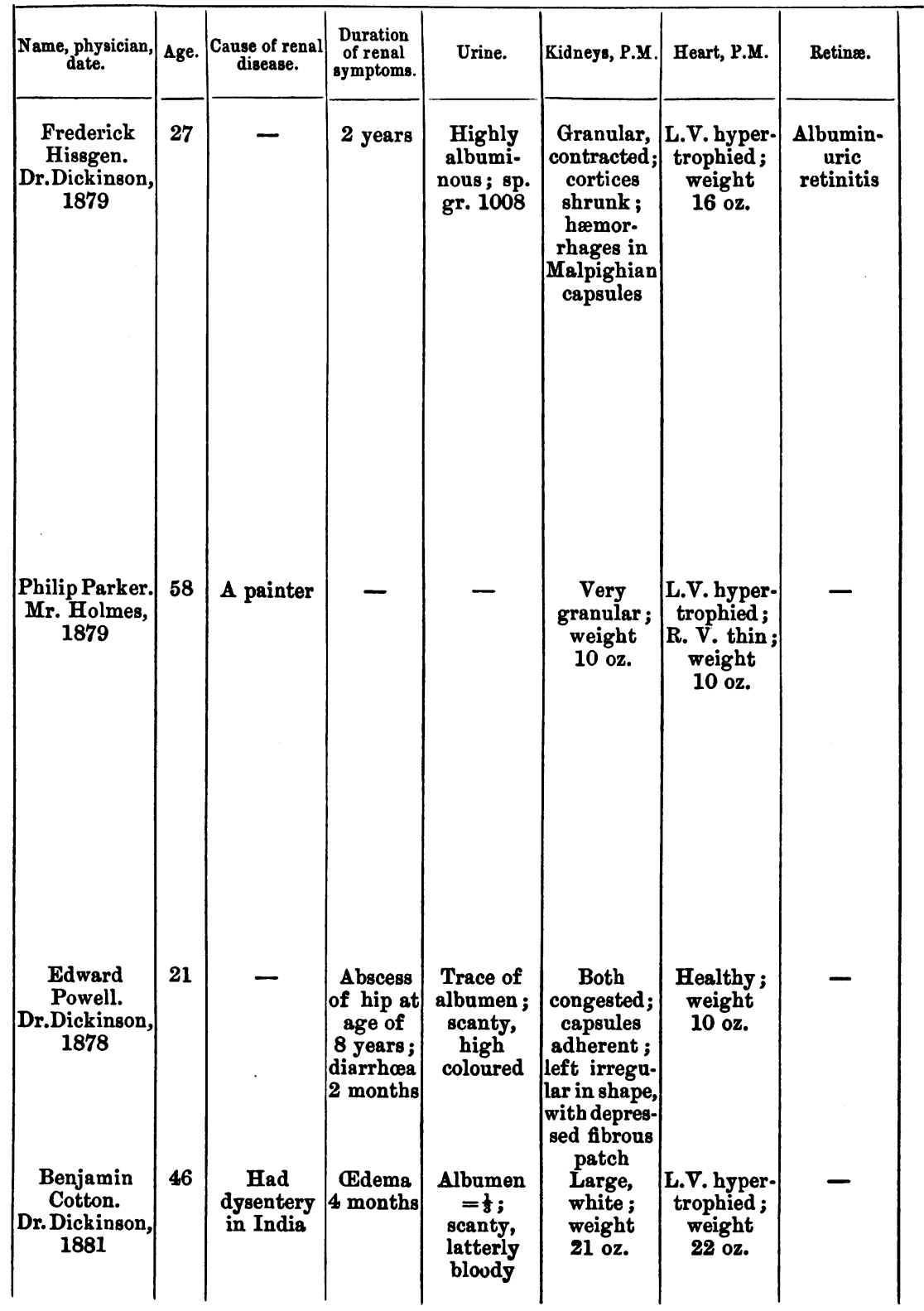




\begin{tabular}{|c|c|} 
Renal symptoms. & Bowel symptoms. \\
\hline ache, vomiting & $\begin{array}{c}\text { Much pain in belly } \\
\text { for 40 days before } \\
\text { death, especially } \\
\text { about umbilicus, } \\
\text { where was tender- } \\
\text { ness; constipa- } \\
\text { tion; hiccough; } \\
\text { no diarrhoa; } \\
\text { latterly delirium }\end{array}$ \\
\cline { 2 - 3 }
\end{tabular}

Examination by Mr. Fenton, 1893.-The submucosa is cedematous and swollen from the presence of recently extravasated blood. Around the hæmorrhages are signs of inflammation, i.e. small-cell infiltration, probably the result of the hæmorrhage. The vessels are engorged with blood, and the walls of the arteries are thickened. There are some pigment masses in the submucosa, probably evidence of former hæmorrhage. The peritoneum has recent lymph on its surface. The mucosa has entirely gone in parts, with, in some places, part of the submucosa ; the removal has the appearance of having been effected by a process of digestion rather than by active inflammation

Admitted with | Bowels confined |Per fracture of thigh; at first, then no renal symptoms recognised

None beside diarrhœa

Edema; some ascites profuse diarrhcea with abdominal pain, tenderness, vomiting, and delirium. Sank from abdominal disturbance, which began 5 days before death

\section{Obstinate}

diarrhce for over

2 months, with exhaustion,

delirium, and death

No bowel symptoms

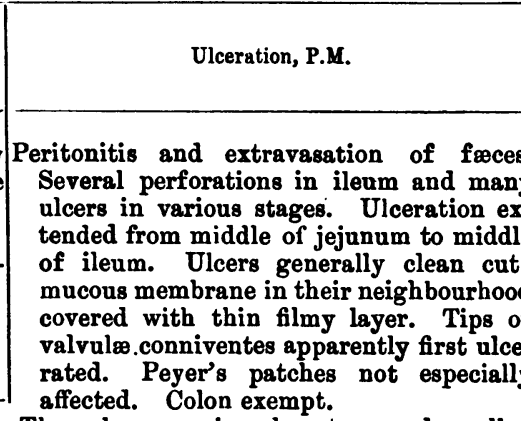

Peritonitis. Descending colon and sig- None. moid flexure thickened and "worm-eaten." Ulceration more or less continuous in these regions, with many recent hæmorrhages. Bowel nearly perforated in several places. Postscript, 1893.-After keeping in spirit punched-out appearance well shown. In many places round, sharp-edged hollows like indentations made by raindrops.

Examination by Mr. Fenton, 1893.-Submucosa œdematous and swollen by recently extravasated blood. Small-cell infiltration around hæmorrhages, as in case of Hissgen, and probably from same cause. The vessels, especially the veins, distended with blood. Pigment masses present. The mucosa has in places been removed as in preceding case Several small ulcers of mucous membrane surrounded by slate-coloured zones of old hæmorrhage, on valve and just above it. Congestion of small intestine and stomach \begin{tabular}{l}
$\begin{array}{c}\text { Disease } \\
\text { bearing } \\
\text { on ulce- } \\
\text { ration. }\end{array}$ \\
\hline None. \\
None. \\
None. \\
None.
\end{tabular} 


\begin{tabular}{|c|c|c|c|c|c|c|c|}
\hline $\begin{array}{c}\text { Name, physician, } \\
\text { date. }\end{array}$ & Age. & $\begin{array}{c}\text { Canse of renal } \\
\text { disease. }\end{array}$ & $\begin{array}{c}\text { Duration } \\
\text { of renal } \\
\text { symptoms. }\end{array}$ & Urine. & Kidneys, P.M. & Heart, P.M. & Retinæ. \\
\hline $\begin{array}{c}\text { Sarah } \\
\text { Greenfield. } \\
\text { Dr.Dickinson, } \\
\mathbf{1 8 8 2}\end{array}$ & 39 & $\begin{array}{c}\text { Repeated } \\
\text { pregnan- } \\
\text { cies (?) }\end{array}$ & $\begin{array}{c}\text { Head- } \\
\text { ache } \\
6 \text { months }\end{array}$ & $\begin{array}{c}\text { Highly } \\
\text { albumin- } \\
\text { ous; sp. } \\
\text { gr. 1012; } \\
\text { polyuria }\end{array}$ & $\begin{array}{c}\text { Granular, } \\
\text { contracted; } \\
\text { weight } \\
\mathbf{8} \text { oz. }\end{array}$ & $\begin{array}{l}\text { L.V. hyper- } \\
\text { trophied; } \\
\text { weight } \\
16 \mathrm{oz} .\end{array}$ & $\begin{array}{l}\text { Albumin- } \\
\text { uric } \\
\text { retinitis }\end{array}$ \\
\hline $\begin{array}{c}\text { Louisa Booth. } \\
\text { Dr.Dickinson, } \\
1883\end{array}$ & 21 & $\begin{array}{c}\text { General } \\
\text { dropsy at } \\
\text { age of 12, } \\
\text { which } \\
\text { lasted 12 } \\
\text { months; } \\
\text { cedema } \\
\text { recurred } \\
4 \text { months } \\
\text { before } \\
\text { death }\end{array}$ & $\begin{array}{c}11 \text { years } \\
(?) ; \\
4 \text { months } \\
(?)\end{array}$ & $\begin{array}{c}\text { Latterly } \\
\text { albumen } \\
=\frac{1}{3} \text {; } \\
\text { polyuria }\end{array}$ & $\begin{array}{l}\text { Larda- } \\
\text { ceous; } \\
\text { weight } \\
9 \text { oz. }\end{array}$ & $\begin{array}{c}\text { Weight } \\
6 \mathrm{oz} .\end{array}$ & - \\
\hline $\begin{array}{c}\text { Ann Harffery. } \\
\text { Dr. Wadham, } \\
1885\end{array}$ & 19 & $\begin{array}{c}\text { Scarlet } \\
\text { fever in } \\
1871 \text {; } \\
\text { nephritis in } \\
1873\end{array}$ & 8 years & $\begin{array}{c}\text { Albumen } \\
=\frac{1}{3} ; \text { casts }\end{array}$ & \begin{tabular}{|} 
Left kidney \\
contracted \\
and \\
fibrotic ; \\
right tubal \\
nephritis
\end{tabular} & $\begin{array}{c}\text { L.V. much } \\
\text { hypertro- } \\
\text { phied ; } \\
\text { weight } \\
10 \text { oz. }\end{array}$ & - \\
\hline $\begin{array}{c}\text { Ann Mackay. } \\
\text { Dr. Wadham, } \\
1885\end{array}$ & 15 & $\begin{array}{l}\text { Scarlatina } \\
\text { in } 1873 \\
(?)\end{array}$ & - & $\begin{array}{l}\text { Albumen } \\
=8 \\
\text { smoky, } \\
\text { scanty; } \\
\text { casts }\end{array}$ & \begin{tabular}{|c|} 
Fibrotic, \\
contracted, \\
pale; \\
capsule \\
adherent; \\
weight 4 oz.
\end{tabular} & $\begin{array}{c}\text { L.V. hyper- } \\
\text { trophied ; } \\
\text { weight } \\
8 \mathrm{oz} .\end{array}$ & - \\
\hline $\begin{array}{c}\text { Ann Shaw. } \\
\text { Dr. } \\
\text { Champneys, } \\
1888\end{array}$ & 49 & $\begin{array}{c}\text { Stricture } \\
\text { of urethra } \\
(?)\end{array}$ & - & $\begin{array}{c}\text { Contained } \\
\text { blood and } \\
\text { pus; } \\
\text { alkaline }\end{array}$ & $\begin{array}{l}\text { Both gra- } \\
\text { nular; right } \\
\text { atrophied ; } \\
\text { left en- } \\
\text { larged and } \\
\text { contained } \\
\text { abscesses }\end{array}$ & \begin{tabular}{|c} 
Old mitral \\
disease ; \\
weight \\
$16 \mathrm{oz}$.
\end{tabular} & $\begin{array}{c}\text { Hæmor- } \\
\text { rhages in } \\
\text { both }\end{array}$ \\
\hline $\begin{array}{c}\text { George } \\
\text { Windover. } \\
\text { Dr.Dickinson, } \\
1889\end{array}$ & 58 & $\begin{array}{l}\text { Painter; } \\
\text { gout }\end{array}$ & - & $\begin{array}{c}\text { Albumen } \\
=\frac{1}{\delta} ; \text { pale; } \\
\text { sp. gr. 1012 }\end{array}$ & $\begin{array}{c}\text { Granular, } \\
\text { contracted, } \\
\text { cysted ; } \\
\text { weight } 6 \text { oz. }\end{array}$ & $\begin{array}{c}\text { L.V.greatly } \\
\text { hypertro- } \\
\text { phied ; } \\
\text { weight 22 } \\
\text { oz.; recent } \\
\text { pericarditis }\end{array}$ & $\begin{array}{c}\text { Albumin- } \\
\text { uric } \\
\text { changes in } \\
\text { both }\end{array}$ \\
\hline
\end{tabular}




\begin{tabular}{|c|c|c|c|}
\hline Renal symptoms. & Bowel symptoms. & Ulceration, P.M. & \begin{tabular}{|l} 
Disease \\
bearing \\
on ulce- \\
ration.
\end{tabular} \\
\hline $\begin{array}{l}\text { No dropsy; head- } \\
\text { ache, vomiting }\end{array}$ & $\begin{array}{c}\text { Acute abdominal } \\
\text { pain with loose- } \\
\text { ness of bowels } \\
2 \text { days before } \\
\text { death }\end{array}$ & $\begin{array}{l}\text { Many pink injected patches on peritoneum. } \\
\text { Many prominent congested villi on small } \\
\text { bowel, some of which are beginning to } \\
\text { ulcerate }\end{array}$ & None. \\
\hline \multicolumn{2}{|c|}{$\begin{array}{l}\text { General dropsy at age of } 12 \text {. One year } \\
\text { before death showed symptoms of } \\
\text { circumscribed abscesses in perito- } \\
\text { neum, due (as was subsequently ascer- } \\
\text { tained) to perforation of intestinal } \\
\text { ulcers, no doubt due to former albu- } \\
\text { minuria; then constant discharge of } \\
\text { pus from bowels, and consequent } \\
\text { establishment of lardaceous disease, } \\
\text { which affected liver, spleen, and kid- } \\
\text { neys. Recurrence of albuminuria } \\
\text { and dropsy, with diarrhœa, vomiting, } \\
\text { and prostration }\end{array}$} & $\begin{array}{l}\text { Irregular ulcers in large intestine, some of } \\
\text { which, in the sigmoid flexure, had perfo- } \\
\text { rated the bowel and were in connection } \\
\text { with the abscess cavity outside; ulcers } \\
\text { irregular in shape, with thin edges. } \\
\text { General lardaceous disease, which was } \\
\text { apparent during life }\end{array}$ & None. \\
\hline $\begin{array}{l}\text { No œdema latterly. } \\
\text { Died with uræmia } \\
\text { and convulsions }\end{array}$ & $\begin{array}{l}\text { Pain in belly } 10 \\
\text { days before death, } \\
\text { which recurred in } \\
\text { severe paroxysms; } \\
\text { formerly constipa- } \\
\text { tion; diarrhœea } \\
\text { latterly, abdomen } \\
\text { resonant and tight }\end{array}$ & $\begin{array}{l}\text { Ileum for } 6 \text { feet contained ulcerated patches } \\
\text { stained with fæcal matter. Ulceration } \\
\text { connected with congestion and interstitial } \\
\text { hæmorrhage. Some of the vessels plugged } \\
\text { by coagula }\end{array}$ & None. \\
\hline $\begin{array}{c}\text { No odema at any } \\
\text { time; epileptiform } \\
\text { fits; urinous smell } \\
\text { in breath. Died } \\
\text { with convulsions }\end{array}$ & None noted & $\begin{array}{l}\text { Ulcers "near cæcum "-the largest } 1 \text { inch } \\
\text { by } \frac{t}{2} \text { inch. Cæcum and colon present } \\
\text { many black patches of the size of pins" } \\
\text { heads, due to intense congestion of solitary } \\
\text { glands. Congestion present in other parts } \\
\text { of bowel, but not to same extent }\end{array}$ & None. \\
\hline $\begin{array}{l}\text { Edema, vomiting; } \\
\text { Died of uræmia }\end{array}$ & $\begin{array}{l}\text { Vomiting } \\
\text { (urmmic ?). No } \\
\text { distinct bowel } \\
\text { symptoms }\end{array}$ & Large ulcer in middle of transverse colon. & None. \\
\hline CEdema, ascites & None recognised & Olcers in transverse colon & None. \\
\hline
\end{tabular}




\begin{tabular}{|c|c|c|c|c|c|c|c|}
\hline $\begin{array}{c}\text { Name, physician, } \\
\text { date. }\end{array}$ & Age. & $\begin{array}{c}\text { Cause of renal } \\
\text { disease. }\end{array}$ & $\begin{array}{c}\text { Duration } \\
\text { of renal } \\
\text { symptoms. }\end{array}$ & Urine. & Kidneys, P.M. & Heart, P.M. & Retinæ. \\
\hline $\begin{array}{c}\text { Henry Webb. } \\
\text { Dr. Ewart, } \\
1890\end{array}$ & 52 & Painter & - & $\begin{array}{l}\text { Loaded } \\
\text { with } \\
\text { albumen }\end{array}$ & $\begin{array}{c}\text { Large, } \\
\text { white; not } \\
\text { lardaceous ; } \\
\text { weight } \\
16 \text { oz. }\end{array}$ & $\begin{array}{l}\text { Weight } \\
14 \mathrm{oz.}\end{array}$ & - \\
\hline $\begin{array}{c}\text { Thomas } \\
\text { Spaul. } \\
\text { Dr. Cavafy, } \\
1890\end{array}$ & 24 & Calculi (?) & 3 months & $\begin{array}{c}\text { Cloud of } \\
\text { albumen; } \\
\text { pale; } \\
\text { sp. gr. } 1010\end{array}$ & \begin{tabular}{|c} 
Both \\
granular ; \\
stones in \\
left ; left \\
weighed \\
1 oz.; \\
right 7 oz.
\end{tabular} & $\begin{array}{c}\text { Both } \\
\text { ventricles } \\
\text { hypertro- } \\
\text { phied; } \\
\text { weight } \\
18 \mathrm{oz.}\end{array}$ & $\begin{array}{l}\text { Albumin- } \\
\text { uric } \\
\text { retinitis ; } \\
\text { hømor- } \\
\text { rhage in } \\
\text { right }\end{array}$ \\
\hline $\begin{array}{l}\text { Henry } \\
\text { Slemon. } \\
\text { Dr. Ewart, } \\
1890\end{array}$ & 56 & $\begin{array}{c}\text { Whiskey } \\
\text { drinking } \\
\text { (?) }\end{array}$ & - & $\begin{array}{l}\text { Albumin. } \\
\text { ous ; } \\
\text { scanty, } \\
\text { bloody }\end{array}$ & \begin{tabular}{|} 
Granular, \\
contracted \\
weight 4 oz.
\end{tabular} & $\begin{array}{c}\text { L.V. hyper- } \\
\text { trophied; } \\
\text { weight } \\
12 \mathrm{oz} .\end{array}$ & - \\
\hline $\begin{array}{c}\text { Jane Moss. } \\
\text { Dr. Cavafy, } \\
1890\end{array}$ & 48 & - & 3 weeks & $\begin{array}{l}\text { Albumin- } \\
\text { ous and } \\
\text { lithatic }\end{array}$ & $\begin{array}{c}\text { Fibrotic; } \\
\text { contained } \\
\text { old } \\
\text { infarcts ; } \\
\text { woight } \\
\mathbf{8 ~ o z .}\end{array}$ & $\begin{array}{c}\text { Both } \\
\text { ventricles } \\
\text { hypertro- } \\
\text { phied; } \\
\text { weight } \\
16 \mathrm{oz} .\end{array}$ & Normal \\
\hline $\begin{array}{c}\text { William } \\
\text { Jones. } \\
\text { Dr. Cavafy, } \\
1891\end{array}$ & 66 & - & 5 years & $\begin{array}{l}\text { Slightly } \\
\text { albumin- } \\
\text { ous ; } \\
\text { copious, } \\
\text { pale }\end{array}$ & $\begin{array}{c}\text { Granular, } \\
\text { red, con- } \\
\text { tained case- } \\
\text { ous masses ; } \\
\text { weight } \\
124 \mathrm{oz} .\end{array}$ & $\begin{array}{c}\text { L.V. hyper- } \\
\text { trophied; } \\
\text { weight } \\
29 \text { oz.; } \\
\text { pericarditis }\end{array}$ & - \\
\hline
\end{tabular}

Ulceration of Stomach possibly Albuminuric,

\begin{tabular}{|c|c|c|c|c|c|c|c|}
\hline $\begin{array}{c}\text { Jessie Bevan. } \\
\text { Dr.Dickinson, } \\
1888\end{array}$ & 17 & 一 & 2 years & $\begin{array}{l}\text { Albumin. } \\
\text { ous ; low } \\
\text { sp. gr. }\end{array}$ & $\mid \begin{array}{c}\text { Contracted, } \\
\text { granular, } \\
\text { fibrotic; } \\
\text { weight } \\
5 \text { oz. }\end{array}$ & $\begin{array}{c}\text { Great } \\
\text { hyper- } \\
\text { trophy of } \\
\text { L.V.; } \\
\text { weight } \\
\text { 16 oz. }\end{array}$ & $\begin{array}{l}\text { Albumin- } \\
\text { uric } \\
\text { changes }\end{array}$ \\
\hline
\end{tabular}




\begin{tabular}{|c|c|c|c|}
\hline Renal symptoms. & Bowel symptoms. & Ulceration, P.M. & $\begin{array}{l}\text { Disease } \\
\text { bearing } \\
\text { on ulce- } \\
\text { ration. }\end{array}$ \\
\hline $\begin{array}{l}\text { Edema, headache, } \\
\text { vomiting, } \\
\text { dyspncea, } \\
\text { drowsiness }\end{array}$ & None noted & $\begin{array}{l}\text { Two sharply cut ulcers in first part of duo- } \\
\text { denum. Mucous membrane of duodenum } \\
\text { injected }\end{array}$ & None. \\
\hline $\begin{array}{c}\text { Headache, } \\
\text { vomiting, } \\
\text { dyspnœa; œdema } \\
\text { latterly }\end{array}$ & None observed & $\begin{array}{l}\text { Ulcer in commencement of duodenum. } \\
\text { Cæcum extensively ulcerated, with blood } \\
\text { in mucous coat. Old ulcers in sigmoid } \\
\text { flexure. Tar-like fæces in colon }\end{array}$ & None. \\
\hline $\begin{array}{l}\text { Edema. Died of } \\
\text { uræmia. Had } \\
\text { also cirrhosis of } \\
\text { liver and ascites }\end{array}$ & None observed & $\begin{array}{l}\text { Ulcer in ascending colon. Hæmorrhage in } \\
\text { mucous coat of sigmoid flexure }\end{array}$ & None. \\
\hline Edema ; delirium & $\begin{array}{c}\text { Diarrhœa ; } \\
\text { motions like those } \\
\text { of typhoid }\end{array}$ & $\begin{array}{l}\text { Intestines discoloured externally at intervals. } \\
\text { Internally discoloured patches to a marked } \\
\text { extent, together with ulceration in the } \\
\text { duodenum. A few patches of ulceration } \\
\text { in the jejunum. Hæmorrhagic patches } \\
\text { in ileum and sigmoid flexure. The hæmor- } \\
\text { rhages were in the submucous coat, and } \\
\text { evidently the primary condition, the } \\
\text { ulceration being secondary }\end{array}$ & $\begin{array}{l}\text { Scars } \\
\text { at } \\
\text { apices } \\
\text { of } \\
\text { lungs. } \\
\end{array}$ \\
\hline $\begin{array}{l}\text { Much œdema ; } \\
\text { mitral systolic } \\
\text { murmur; } \\
\text { dyspnœea; epis- } \\
\text { taxis }\end{array}$ & None observed & $\begin{array}{l}\text { One large and two small shallow ulcers in } \\
\text { the first part of the duodenum; no thick- } \\
\text { ening; no trace of new growth }\end{array}$ & None. \\
\hline \multicolumn{4}{|c|}{ with or without Ulceration of the Bowel. } \\
\hline $\begin{array}{l}\text { Edema, headache, } \\
\text { vomiting }\end{array}$ & $\mid \begin{array}{c}\text { Epigastric pain } \\
\text { after food (ulcers } \\
\text { of stomach); } \\
\text { much abdominal } \\
\text { pain and vomiting }\end{array}$ & \begin{tabular}{|} 
Several small ulcers in stomach, the largest \\
about size of threepenny piece. Numerous \\
ulcers from upper part of ileum to lower \\
part of descending colon, in early stage. \\
Mucous membrane thickened and ulcers \\
"punched out." Numerous small brownex- \\
travasations beneath peritoneum of ileum
\end{tabular} & None. \\
\hline
\end{tabular}




\begin{tabular}{|c|c|c|c|c|c|c|c|}
\hline $\begin{array}{c}\text { Name, physician, } \\
\text { date. }\end{array}$ & Age. & $\begin{array}{l}\text { Cause of renal } \\
\text { disease. }\end{array}$ & $\begin{array}{c}\text { Duration } \\
\text { of renal } \\
\text { symptoms. }\end{array}$ & Urine. & Kidneys, P.M. & Heart, P.M. & Retinæ. \\
\hline $\begin{array}{c}\text { Emily Potter. } \\
\text { Dr.Dickinson, } \\
1881\end{array}$ & 8 & - & 7 months & $\begin{array}{c}\text { Albumen } \\
=\frac{1}{8} ; \\
\text { alkaline }\end{array}$ & $\begin{array}{c}\text { Interstitial } \\
\text { nephritis; } \\
\text { unequal in } \\
\text { size. } \\
\text { Bladder } \\
\text { hyper- } \\
\text { trophied }\end{array}$ & $\begin{array}{c}\text { L.V. } \\
\text { greatly } \\
\text { hyper- } \\
\text { trophied; } \\
\text { weight } \\
5 \frac{1}{2} \text { oz. }\end{array}$ & - \\
\hline $\begin{array}{c}\text { EmmaKillick. } \\
\text { Dr.Dickinson, } \\
1891\end{array}$ & 53 & - & 3 weeks & $\begin{array}{c}\text { Albumen } \\
=\frac{1}{8} ; \\
\text { lithatic }\end{array}$ & $\begin{array}{c}\text { Red, } \\
\text { granular ; } \\
\text { weight } \\
10 \mathrm{oz} .\end{array}$ & \begin{tabular}{|} 
Hyper- \\
trophy and \\
dilation of \\
L.V.; \\
weight \\
17 oz.
\end{tabular} & - \\
\hline
\end{tabular}

\section{Cases of Intestinal Hæmorrhage}

\begin{tabular}{|c|c|c|c|c|c|c|c|}
\hline $\begin{array}{c}\text { Charlotte } \\
\text { Rayner. } \\
\text { Dr. Cavafy, } \\
1887\end{array}$ & 40 & $\begin{array}{c}\text { Pregnan- } \\
\text { cies (?) }\end{array}$ & 7 months & $\begin{array}{c}\text { Blood and } \\
\text { pus }\end{array}$ & $\begin{array}{c}\text { Granular, } \\
\text { contracted ; } \\
\text { weight } \\
6 \mathrm{oz} .\end{array}$ & $\mid \begin{array}{c}\text { L.V. hyper- } \\
\text { trophied ; } \\
\text { weight } \\
17 \mathrm{oz} .\end{array}$ & $\begin{array}{l}\text { Albumin- } \\
\text { uric } \\
\text { retinitis }\end{array}$ \\
\hline $\begin{array}{c}\text { Edward } \\
\text { Heath. } \\
\text { Mr. Pick, } \\
1890\end{array}$ & 42 & - & - & - & $\begin{array}{l}\text { Highly } \\
\text { granular; } \\
\text { cortices } \\
\text { shrunk; } \\
\text { weight } \\
10 \mathrm{oz} .\end{array}$ & $\begin{array}{c}\text { Enormous } \\
\text { hyper- } \\
\text { trophy of } \\
\text { L.V.; } \\
\text { weight } \\
20 \text { oz. }\end{array}$ & $\begin{array}{l}\text { Hæmor- } \\
\text { rhages in } \\
\text { both }\end{array}$ \\
\hline $\begin{array}{c}\text { Elizabeth } \\
\text { Lucy. } \\
\text { Dr.Dickinson, } \\
1890 \\
.\end{array}$ & 47 & - & $\begin{array}{c}12 \text { years } \\
(?) \cdot \\
2 \text { months } \\
(?)\end{array}$ & $\begin{array}{c}\text { Solid with } \\
\text { albumen ; } \\
\text { scanty, } \\
\text { bloody }\end{array}$ & $\begin{array}{c}\text { Congested; } \\
\text { cortices } \\
\text { swollen; } \\
\text { weight } \\
16 \mathrm{oz} .\end{array}$ & $\begin{array}{c}\text { Weight } \\
12 \text { oz.; } \\
\text { recent peri- } \\
\text { carditis }\end{array}$ & - \\
\hline $\begin{array}{l}\text { Henry Fowler. } \\
\text { Dr. Whipham, } \\
1891\end{array}$ & 43 & $\begin{array}{l}\text { Painter ; } \\
\text { gout }\end{array}$ & 3 months & $\begin{array}{l}\text { Albumen } \\
=\frac{1}{10} ; \text { pale; } \\
\text { sp. gr. 1010 }\end{array}$ & $\begin{array}{c}\text { Granular, } \\
\text { cysted; } \\
\text { cortices } \\
\text { shrunk; } \\
\text { weight } 9 \text { oz. }\end{array}$ & $\begin{array}{c}\text { Hyper- } \\
\text { trophy of } \\
\text { both } \\
\text { ventricles; } \\
\text { weight } \\
23 \text { oz. }\end{array}$ & - \\
\hline
\end{tabular}




\begin{tabular}{|c|c|c|c|}
\hline Renal symptoms. & Bowel symptoms. & Ulceration, P.M. & $\begin{array}{l}\text { Disease } \\
\text { bearing } \\
\text { on nlce- } \\
\text { ration. }\end{array}$ \\
\hline $\begin{array}{l}\text { Swelling of face; } \\
\text { no general œdema; } \\
\text { wasting; much } \\
\text { cardiac tension; } \\
\text { gums spongy and } \\
\text { bleeding }\end{array}$ & $\begin{array}{l}\text { Vomiting, diar- } \\
\text { rhœea. Day before } \\
\text { death sudden } \\
\text { agonising pain in } \\
\text { abdomen (perfo- } \\
\text { ration) }\end{array}$ & $\begin{array}{l}\text { Recent peritonitis. Local extravasation of } \\
\text { fæces. Small intestine from about the } \\
\text { middle shows extensive erosions of mucous } \\
\text { membrane, with several well-marked ulcers } \\
\text { opposite the mesentery; three of these in } \\
\text { the last foot of the ileum perforated; no } \\
\text { thickening about them. Similar ulcers in } \\
\text { cæcum and colon. Intestines deeply stained } \\
\text { with extravasated blood; fæcal contents } \\
\text { also blood-stained. Stomach shows an ulcer } \\
\text { near the pylorus, of the size of a sixpence, } \\
\text { surrounded by traces of old extravasation } \\
\text { of blood }\end{array}$ & 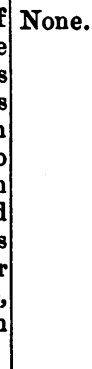 \\
\hline $\begin{array}{l}\text { Much œdema; } \\
\text { systolic murmur } \\
\text { at apex; hæmo- } \\
\text { ptysis; fluid in } \\
\text { pleura }\end{array}$ & $\begin{array}{c}\text { "Indigestion" } \\
\text { for } 3 \text { years } \\
\text { before death }\end{array}$ & $\begin{array}{l}\text { Several small ulcers in stomach, with several } \\
\text { cicatrices of healed ulcers. Surface of } \\
\text { stomach congested and covered with } \\
\text { mucus }\end{array}$ & fl \\
\hline
\end{tabular}

in connection with Albuminuria.

\begin{tabular}{|c|} 
Vomiting \\
Repeated epilepti- \\
form fits after a \\
fall
\end{tabular}

\section{None noted}

None noted

None observed

None observed

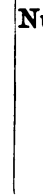

Small intestine congested, and small patches None. of hæmorrhage in mucous membrane. No ulcers

Numerous hæmorrhagic patches throughout None. large and small intestines, and also on stomach

Extensive ecchymoses in cæcum. No ulcers None.

VOL. LXXVII. 


\begin{tabular}{|c|c|c|c|c|c|c|c|}
\hline $\begin{array}{l}\text { Name, physician, } \\
\text { date. }\end{array}$ & $\Delta g$. & $\begin{array}{l}\text { Cause of renal } \\
\text { disease. }\end{array}$ & $\begin{array}{c}\text { Duration } \\
\text { of renal } \\
\text { symptoms. }\end{array}$ & Urine. & Kidneys, P.M. & Heart, P.M. & Retinæ. \\
\hline $\begin{array}{c}\text { William } \\
\text { Werby. } \\
\text { Dr. Whipham, } \\
1891\end{array}$ & 61 & - & 7 months & $\begin{array}{c}\text { Nearly solid } \\
\text { with } \\
\text { albumen; } \\
\text { scanty }\end{array}$ & $\begin{array}{c}\text { Small, } \\
\text { white, } \\
\text { smooth; not } \\
\text { lardaceous ; } \\
\text { weight } \\
12 \text { oz. }\end{array}$ & $\begin{array}{c}\text { Hyper- } \\
\text { trophy of } \\
\text { L.V.; } \\
\text { weight } 25 \\
\text { oz.; recent } \\
\text { pericarditis }\end{array}$ & $\begin{array}{l}\text { Advanced } \\
\text { albumin- } \\
\text { uric de- } \\
\text { generation; } \\
\text { hæmor- } \\
\text { rhages }\end{array}$ \\
\hline $\begin{array}{c}\text { Richard } \\
\text { Seymour. } \\
\text { Dr.Dickinson, } \\
1892\end{array}$ & 46 & - & 5 months & $\begin{array}{l}\text { Albumen } \\
=\frac{1}{2} ; \\
\text { scanty }\end{array}$ & $\begin{array}{l}\text { Granular, } \\
\text { cysted; } \\
\text { cortices } \\
\text { shrunk; } \\
\text { weight } \\
12 \text { o7. }\end{array}$ & $\begin{array}{c}\text { L.V. hyper- } \\
\text { trophied; } \\
\text { weight } \\
30 \text { oz.; } \\
\text { recent peri- } \\
\text { carditis }\end{array}$ & $\begin{array}{c}\text { Small } \\
\text { hæmor- } \\
\text { rhage in } \\
\text { left }\end{array}$ \\
\hline $\begin{array}{c}\text { John Read. } \\
\text { Dr. Whipham, } \\
1892\end{array}$ & 37 & Drink (?) & - & $\begin{array}{l}\text { Albumen } \\
= \pm ; \\
\text { pale }\end{array}$ & $\begin{array}{c}\text { Small, red, } \\
\text { granular, } \\
\text { cysted; } \\
\text { weight } \\
61 \mathrm{oz} .\end{array}$ & $\begin{array}{c}\text { Great } \\
\text { hyper- } \\
\text { trophy of } \\
\text { L.V.; } \\
\text { weight } \\
18 \mathrm{oz.}\end{array}$ & - \\
\hline $\begin{array}{c}\text { John Reardon. } \\
\text { Dr.Dickinson, } \\
1892\end{array}$ & 28 & - & 1 month & $\begin{array}{c}\text { Albumen } \\
=\frac{1}{2} ; \\
\text { scanty }\end{array}$ & $\begin{array}{c}\text { Tubal } \\
\text { nephritis ; } \\
\text { congested; } \\
\text { weight } \\
13 \mathrm{oz} .\end{array}$ & $\begin{array}{l}\text { Hyper- } \\
\text { trophy of } \\
\text { L.V.; } \\
\text { weight } \\
16 \text { oz. }\end{array}$ & $\begin{array}{l}\text { Hæmor- } \\
\text { rhages and } \\
\text { inflamma- } \\
\text { tory } \\
\text { effusion }\end{array}$ \\
\hline
\end{tabular}

(For report of the discussion on this paper, see 'Proceedings of the 
ALBUMINURIC ULCERATION OF THE BOWELS. 131

\begin{tabular}{|c|c|c|c|}
\hline Renal symptoms. & Bowel symptoms. & Ulceration, P.M. & $\begin{array}{l}\text { Disease } \\
\text { bearing } \\
\text { on ulce- } \\
\text { ration. }\end{array}$ \\
\hline $\begin{array}{l}\text { Edema ; bron- } \\
\text { chitis : dyspnœa ; } \\
\text { uræmic smell }\end{array}$ & None observed & $\begin{array}{l}\text { Small submucous hæmorrhages throughout } \\
\text { small intestine. A pigment mass in sig- } \\
\text { moid flexure. No ulceration anywhere }\end{array}$ & $\begin{array}{l}\text { Old } \\
\text { romica } \\
\text { at } \\
\text { apex. }\end{array}$ \\
\hline $\begin{array}{l}\text { Edema ; arterial } \\
\text { tension } 3 \text { dyspncea }\end{array}$ & None observed & $\begin{array}{l}\text { A few submucous hæmorrhages in ileum. } \\
\text { Small pigmented area in ascending colon. } \\
\text { No ulcers }\end{array}$ & None. \\
\hline $\begin{array}{c}\text { No œdema; } \\
\text { alcoholic paralysis }\end{array}$ & None noted & $\begin{array}{l}\text { Several ecchymosed areas in ileum. No } \\
\text { ulcers }\end{array}$ & None. \\
\hline $\begin{array}{c}\text { Much dropsy ; } \\
\text { tense pulse; } \\
\text { bronchitis; } \\
\text { uræmia }\end{array}$ & None observed & $\begin{array}{l}\text { Lower part of ileum and cæcum show nume- } \\
\text { rous small submucous hæmorrhages. No } \\
\text { ulceration or pigmentation }\end{array}$ & None. \\
\hline
\end{tabular}

Rojal Medical and Chirurgical Society,' Third Series, vol. vi, p. 37.) 